\title{
UJI KEPRAKTISAN LEMBAR KERJA SISWA YANG MENGGUNAKAN PENDEKATAN SAINTIFIK
}

\author{
Ayu Sayu Mas Megananda ${ }^{1}$, I Gusti Lanang Wiratma², I Dewa Ketut Sastrawidana ${ }^{3}$ \\ 1,2,3 Universitas' Pendidikan Ganesha \\ Singaraja, Indonesia \\ e-mail: ayu.sayu.mas@undiksha.ac.id¹, lanang.wiratma@undiksha.ac.id², \\ ketut.sastrawidana@undiksha.ac.id ${ }^{3}$
}

\begin{abstract}
Abstrak
Penelitian ini bertujuan untuk mendeskripsikan dan menjelaskan kepraktisan LKS pada pembelajaran kimia pokok bahasan larutan elektrolit dan nonelektrolit yang menggunakan pendekatan saintifik. Penelitian ini merupakan penelitian pengembangan yang dilakukan dengan beberapa tahap, yaitu: (1) pengumpulan data; (2) desain produk; (3) validasi desain; (4) revisi desain (5) uji coba produk; dan (6) revisi produk. Validitas LKS melibatkat dua ahli isi, satu ahli bahasa, dan dua praktisi. Uji coba produk dilakukan dengan uji coba lapangan terbatas yang melibatkan sembilan siswa kelas XI SMAN 1 Kuta Selatan. Hasil uji kepraktisan diperoleh bahwa siswa memberikan respon positif terhadap LKS menggunakan pendekatan saintifik
\end{abstract}

Kata kunci: Lembar Kerja Siswa, Pendekatan Saintifik, Larutan Elektrolit Dan Nonelektrolit.

\begin{abstract}
This study was conducted aimed at describing and explaining the practicality of LKS in learning the subject chemistry of electrolyte and non-electrolyte solutions that use a scientific approach. This research is a development research carried out in several stages, namely: (1) data collection; (2) product design; (3) design validation; (4) design revisions (5) product trials; and (6) product revisions. The validity of the LKS involved two content experts, one linguist, and two practitioners. The product trial was conducted with a limited field trial involving nine students of class XI SMAN 1 Kuta Selatan. The practicality test results obtained that students gave a positive response to the LKS using a scientific approach
\end{abstract}

Keywords: Student Worksheets, Scientific Approach, Electrolyte Solutions And Nonelectrolytes 


\section{PENDAHULUAN}

Lembar Kerja Siswa (LKS) merupakan salah satu media yang digunakan di sekolah dalam kegiatan pembelajaran. LKS juga menjadi salah satu media yang sangat efektif untuk meningkatkan prestasi dan hasil belajar siswa. Hal ini didukung dengan hasil penelitian yang telah dilakukan oleh Yildirim pada tahun 2011 bahwa LKS dapat meningkatkan hasil belajar, terlihat dari rata-rata nilai yang diperoleh meningkat menjadi 80,54 dari nilai rata-rata sebelumnya 59,63. Kegiatan pembelajaran dengan menggunakan LKS juga dapat membantu siswa untuk lebih memahami materi yang sedang diajarkan dengan masalah-masalah yang diberikan dalam LKS tersebut (Diani, 2016). LKS yang digunakan di sekolah diharapkan dapat membantu keterlaksanaan kurikulum 2013. Pada proses pembelajaran kurikulum 2013 disarankan untuk menerapkan pendekatan saintifik (scientific approach) (Permendikbud, 2013). Pendekatan saintifik diharapkan mampu mempersiapkan generasi yang berpikir kritis dan berketerampilan. Pendekatan saintifik adalah proses pembelajaran yang membuat siswa lebih aktif untuk mengonstruksi konsep, hukum, atau prinsip yang ditemukan (Daryanto, 2014). Salah satu penerapan pendekatan saintifik yaitu dengan menggunakan pengalaman belajar dengan urutan logis yang meliputi mengamati, menanya, mengumpulkan informasi, mengasosiasi, dan mengomunikasikan (Permendikbud, 2013). Kelima proses pembelajaran ini merupakan pembelajaran dengan tahapan $5 \mathrm{M}$.

Penerapan tahapan $5 \mathrm{M}$ dapat diaplikasikan dalam pembuatan LKS, yang bertujuan untuk dapat mencapai tujuan kurikulum 2013. Penggunaan pendekatan saintifik dengan tahapan $5 \mathrm{M}$ dapat membantu siswa memahami materi yang sedang diajarkan dengan hasil belajar yang lebih baik dari sebelumnya (Daini, 2016). Pendekatan saintifik dengan tahapan $5 \mathrm{M}$ meliputi lima langkah, yaitu: (1) proses mengamati, dalam hal ini yang dimaksud adalah fenomena yang diberikan (2) kegiatan menanya, dengan harapan mengembangkan kreativitas, kemampuan merumuskan pertanyaan untuk membentuk pikiran kritis (3) kegiatan mengumpulkan informasi sebagai tindak lanjut dari kegiatan menanya (4) kegiatan mengasosiasi, yaitu memilah informasi yang telah didapat (5) mengomunikasikan pelajaran yang telah diperoleh (permendikbud, 2013).

Pengunaan tahapan $5 \mathrm{M}$ dalam LKS sangat efektif dilakukan guna menarik perhatian siswa dalam proses pembelajaran. Dengan LKS yang didalamnya terdapat tahapan $5 \mathrm{M}$ dapat membangun pemahaman siswa karena adanya tahapan yang jelas di dalam pengerjaan LKS (Putri, 2016). Siswa akan tertarik belajar apabila materinya mudah dipahami, namun siswa akan merasa bosan apabila merasa susah memahami materinya (Agustin, 2011).

Berdasarkan hasil observasi yang telah dilakukan di SMA Negeri 1 Sukasada dan SMA Negeri 2 Singaraja, LKS yang digunakan adalah LKS kimia kurikulum 2013 kelas X terbitan Viva Pakarindo tahun 2013. Dalam LKS tersebut memuat uraian singkat materi, latihan-latihan soal, petunjuk eksperimen dengan prosedur yang telah diberikan, kegiatan analisis data. Pada LKS tersebut belum menggunakan pendekatan saintifik sepenuhnya sesuai dengan yang disarankan. Kurikulum 2013 mempunyai pandangan bahwa pengetahuan tidak dapat dipindahkan begitu saja dari guru ke anak didik, namun siswa yang harus memiliki kemampuan secara aktif mencari, mengolah, mengkonstruksi dan menggunakan pengetahuan. Penggunaan LKS yang sesuai dengan tujuan kurikulum 2013 seharusnya berisi tahapan-tahapan yang dapat mengkontruksi pemahaman siswa yang akan mengarahkan siswa menjadi lebih aktif. Tahapan-tahapan tersebut berupa perintah atau arahan yang harus dilakukan siswa yang diakhiri dengan menyimpulkan.

Penggunaan LKS yang belum sepenuhnya menggunakan pendekatan saintifik, tidak hanya menghambat keterlaksaan kurikulum 2013, tetapi bedampak pada hasil belajar siswa. Salah satu pembelajaran yang dianggap sulit oleh siswa adalah pebelajaran kimia pokok bahasan larutan elektrolit dan nonelektrolit. Berdasarkan hasil observasi siswa kurang aktif dan nilai siswa yang rendah. Di beberapa sekolah yang telah dilakukan penelitian oleh Pinta Medina juga terdapat permasalahan dalam pembelajaran kimia pokok bahasan larutan elektrolit dan nonelektrolit. Siswa mengalami miskonsepsi pada materi tersebut, hal ini dikarenakan pemahaman konsep yang rendah. Pelajaran kimia merupakan pembelajaran yang berkelanjutan yang mana pokok bahasan sebelum dan setelahnya akan saling berkaitan. Hal ini menuntut siswa harus memahami dengan baik konsep-konsep pada pokok bahasan yang sedang diajarkan (Medina, 2015).

Berdasarkan permasalahan tersebut maka perlu dilakukan pengujian kepraktisan LKS yang menggunakan pendekatan saintifik. Penelitian ini untuk membuktikan bahwa LKS larutan elektrolit dan nonelektrolit menggunakan pendekatan saintifik dapat digunakan oleh siswa. 


\section{METODE}

Jenis penelitian yang digunakan adalah penelitian pengembangan. Penelitian pengembangan adalah suatu proses yang dilakukan dalam rangka mengembangkana suatu produk yang telah ada (Sugiono, 2016). Dengan dilakukan penelitian pengembangan ini akan menghasilkan suatu produk LKS yang dikembangkan menggunakan pendekatan saintifik dengan langkah pembelajaran $5 \mathrm{M}$ pada topik larutan elektrolit dan larutan nonelektrolit.

Rancangan penelitian ini mengadaptasi dari tahap $R$ \& $D$. Prosedur penelitian $R$ \& $D$ terdapat sepuluh tahap, yaitu 1) potensi dan masalah, 2) pengumpulan data, 3) desain produk, 4) validasi desain, 5) revisi desain, 6) uji coba pemakaian, 7) revisi produk, 8) uji coba pemakaian, 9) revisi produk, dan 10) produksi masal (sugiono, 2016). Pada penelitian pengembangan ini yang dilakukan hanya enam tahap, yaitu: 1) pengumpulan data, 2) desain produk, 3) validasi desain, 4) revisi desain, 5) uji coba produk, dan 6) revisi produk.

\section{HASIL DAN PEMBAHASAN}

Pengembangan LKS dengan pendekatan saintifik ini diawali dengan pengumpulan data. Data yang dikumpulkan berupa LKS yang dikembangkan dan telah divalidasi. Penyusunan LKS menggunakan pendekatan saintifik yang dikembangkan dilakukan dengan melakukan bimbingan. Penyusunan LKS secara garis besar dilakukan dengan menentukan komponen LKS, indikator sesuai dengan kompetensi dasar yang ingin dicapai, dan kegiatan pembelajaran $5 \mathrm{M}$. Komponen LKS yang dikembangkan meliputi: (1) sampul depan yang berisi judul LKS secara keseluruhan dengan identitas penulis; (2) prakarta; dan (3) daftar isi. Komponen yang dikembangkan pada masing-masing LKS meliputi: (1) sampul depan yang berisi judul dan kolom identitas siswa dalam satu kelompok serta alokasi waktu pengerjaan, (2) tujuan pembelajaran, (3) petunjuk penggunaan LKS, (4) pengantar, (5) kegiatan mengamati, (6) merumuskan pertanyaan, (7) mengumpulkan data, (8) mengasosiasi, dan (9) kegiatan mengomunikasikan. Hal ini sudah sesuai dengan syarat yang harus ada dalam penulisan LKS menurut Depdiknas (2008) bahwa dalam penulisan LKS meliputi: (1) judul, (2) petunjuk belajar, (3) kompetensi yang akan dicapai, (4) informasi pendukung, dan (5) tugas dan langkah-langkah kerja. Berdasarkan hal tersebut dapat disimpulkan bahwa komponen LKS yang dikembangkan sudah termasuk dalam kategori lengkap.

LKS yang dikembangkan menggunakan pendekatan saintifik memiliki karakteristik dengan kegiatan 5 M. Hal ini sesuai dengan Permendikbud RI nomor 81A Tahun 2013, bahwa penerapan kurikulum 2013 dalam pembelajaran diharapkan menggunakan pendekatan saintifik, salah satunya dengan kegiatan $5 \mathrm{M}$. Kegiatan $5 \mathrm{M}$ meliputi: (1) kegiatan mengamati, dalam LKS ini siswa melakukan pengamatan terhadap demonstrasi yang dilakukan oleh guru, kemudian siswa melakukan pencatatan hasil pengamatan pada kolom yang telah disediakan. Pencatatan hasil pengamatan dilakukan untuk mengetahui keterampilan proses dalam pengoptimalan panca indera dalam memperoleh informasi (Kesiman, 2017); (2) kegiatan menanya yang menuntut siswa untuk membuat pertanyaan yang belum dipahami dari hasil pengamatan. Hal ini sesuai menurut Hosnan (2014), bertanya akan mendorong dan menginspirasi siswa untuk aktif belajar, serta membangkitkan keterampilan siswa dalam berbicara menggunakan bahasa yang baik dan benar; (3) kegiatan mengumpulkan data yang dilakukan untuk mencari jawaban dengan eksperimen dan membaca berbagai sumber; (4) kegiatan mengasosiasi yang dilakukan dengan mengolah datadata yang diperoleh pada kegiatan mengumpulkan data hingga diperoleh suatu kesimpulan; dan (5) kegiatan mengomunikasikan yang dilakukan dengan menyampaikan hasil diskusi. LKS yang dikembangkan dengan pendekatan saintifik juga menggunakan bahasa yang sesuai dengan Pedoman Umum Ejaan Bahasa Indonesia sehingga mempermudahkan siswa dalam mengerjakan LKS. Hal ini sesuai dengan syarat konstruksi yang harus ada dalam LKS menurut Hendro dan Kaligis (1993) bahwa LKS harus menggunakan struktur kalimat yang jelas dan sesuai dengan tingkat perkembangan siswa.

LKS larutan elektrolit dan nonelektrolit yang telah digunakan di sekolah adalah LKS untuk SMA/MA kelas X Karangan Tim Penyusun MIPA Tahun 2013, Penerbit Viva Pakarindo. LKS tersebut tersusun atas: (1) pengantar yang berupa uraian singkat materi dan contoh; kegiatan percobaan yang disajikan dilengkapi dengan langkah kerja; dan (3) terdapat soal-soal latihan dan kesimpulan. Pada LKS ini tidak adanya kegiatan merumuskan pertanyaan, setelah pengantar yang berupa uraian singkat materi dan contoh, siswa langsung diarahkan untuk melakukan percobaan.

Perbedaan terlihat dari LKS yang dikembangkan menggunakan pendekatan saintifik dengan LKS Kimia Karangan Tim Penyusun MIPA Tahun 2013. Pada LKS Kimia Karangan Tim Penyusun MIPA belum menggunakan pendekatan saintifik sepenuhnya, hal ini terlihat dari tidak adanya tahap merumuskan pertanyaan, namun langsung menuju pada pengumpulan data. Praktikum yang dilakukan pada LKS kimia Karangan Tim Penyusun MIPA hanya diberikan satu 
kali selama pokok bahasan larutan elektrolit dan nonelektrolit, sedangkan pada LKS yang telah dikembangkan memberikan kesempatan untuk melakukan praktikum di masing-masing sub topik dan LKS yang dikembangkan sudah menggunakan pendekatan saintifik dengan kegiatan $5 \mathrm{M}$.

Produk LKS yang telah dikembangkan menggunakan pendekatan saintifik divalidasi oleh ahli isi, ahli bahasa, dan praktisi. Hasil validasi ahli isi, ahli bahasa, dan praktisi secara keseluruhan diperoleh skor 3,77 dengan katagori sangat valid. Kevalidan LKS yang dikembangkan sesuai dengan kriteria validitas LKS dari Sadra dalam penelitian Wiliudiari tahun 2015, bahwa LKS dapat dikatakakan valid jika memperoleh skor diatas 2,5 dan sangat valid jika memperoleh nilai diatas 3,5. Pada uji validisi, ahli dan praktisi juga meberikan beberapa masukan yang perlu direvisi untuk menyempurnakan produk. Hal ini sesuai dengan teori pengembangan R\&D bahwa setelah produk divalidasi oleh para ahli akan diketahui kekurangan dari produk yang dikembangkan sehingga kekurangan dari produk tersebut dikurangi dengan cara memperbaiki produk dan selanjutnya dilakukan uji coba produk (Sugiyono, 2016).

Pada penelitian ini uji coba produk dilakukan dengan uji coba lapangan terbatas. Tujuan dilakukannya uji coba lapangan terbatas adalah untuk mengetahui kepraktisan dari LKS yang telah dikembangkan. Kegiatan uji coba lapangan terbatas dilaksanakan di SMA Negeri 1

Kuta Selatan dengan menggunakan sembilan siswa. LKS yang diuji cobakan sebanyak 2 LKS dengan waktu masing-masing 2 jam pelajaran. Data-data pada kegiatan uji coba diperoleh melalui metode observasi, angket dan wawancara.

Pada saat pembelajaran dengan LKS menggunakan pendekatan saintifik, siswa mengerjakan bersama kelompoknya, hal ini agar siswa dapat mendiskusikan bersama temannya. Dengan adanya diskusi maka siswa menjadi lebih aktif menyampaikan pendapatnya, sehingga materi yang dipelajari dapat lebih dikuasai. Selama pembelajaran berlangsung peneliti melakukan observasi terhadap prilaku siswa disetiap kegiatan. Berdasarkan hasil observasi dari LKS 1, siswa terlihat memperhatikan dan mengikuti arahan yang diberikan dengan baik, mengerjakan LKS dengan bersungguh-sungguh dan teliti, dan semua siswa terlihat aktif dalam kelompoknya masingmasing. Hasil observasi dari LKS 2 hampir sama dengan hasil observasi LKS 1, perbedaannya terletak pada ketelitian dari salah satu kelompok yang kurang dalam mengamati demonstrasi, namun kekurangan tersebut telah disadari saat pengumpulan data. Berdasarkan waktu pengerjaan LKS, baik LKS 1 maupun LKS 2 sudah sesuai dengan yang diharapkan, dengan demikian dapat dikatakan bahwa kedua LKS yang dikembangkan dapat digunakan oleh siswa.

Pengambilan data kedua dilakukan dengan pengisian angket respon siswa terhadap LKS yang dikembangkan. Angket respon siswa terdiri dari empat aspek, yaitu daya tarik, isi LKS, motivasi diri, dan bahasa. Hasil angket yang telah diisi oleh siswa memperoleh respon yang positif terhadap LKS yang dikembangkan. Dengan demikian LKS pembelajaran kimia pokok bahasan larutan elektrolit dan nonelektrolit menggunakan pendekatan saintifik dapat dikatakan menarik dan dapat meotivasi siswa.

Data ketiga yang diperoleh dari pelaksanaan uji coba lapangan terbatas adalah data wawancara. Wawancara dilakukan untuk memperoleh kesan siswa terhadap LKS yang dikembangkan. Tanggapan sembilan siswa terhadap LKS pembelajaran kimia pokok bahasan larutan elektrolit dan nonelektrolit menggunakan pendekatan saintifik sangat baik. Siswa merasa terbantu dan tidak merasa bosan dengan menerapkan LKS yang menggunakan pendekatan saintifik dalam kegiatan pembelajaran. Dengan tanggapan siswa tersebut maka dapat dikatakan bahwa LKS pembelajaran kimia pokok bahasan larutan elektrolit dan nonelektrolit menggunakan pendekatan saintifik memudahkan siswa dalam kegiatan pembelajaran.

Berdasarkan data dari ketiga metode tersebut dapat disimpulkan bahwa LKS pembelajaran kimia pokok bahasan larutan elektrolit dan nonelektrolit menggunakan pendekatan saintifik secara keseluruhan sudah dapat digunakan oleh siswa pada pembelajaran di kelas. Kegiatan $5 \mathrm{M}$ yang ada di setiap LKS dapat diikuti dengan baik. Pada kegiatan mengamati siswa terlihat fokus dan bersungguh-sungguh memperhatikan, sehingga semua siswa dapat mengisi hasil pengamatan sesuai dengan yang diharapkan. Pada kegiatan menanya siswa mampu merumuskan pertanyaan sesuai dengan hasil pengamatan yang telah diperoleh pada kegiatan sebelumnya. Pada kegiatan mengumpulkan data siswa sungguh-sungguh dalam melakukan percobaan, semua siswa terlihat aktif bekerja dalam kelompoknya masing-masing. Pada kegiatan megasosiasi siswa mengolah data yang telah diperoleh bersama kelompok dengan baik. Pada kegiatan mengomunikasikan siswa dapat menyampaikan hasil diskusinya dengan baik dan jelas. Kesungguhan siswa dalam mengerjakan LKS menunjukan bahwa siswa tidak merasa kesulitan memahami materi yang diberikan. Hal ini sesuai dengan pendapat Agustin (2011) bahwa siswa akan tertarik belajar apabila materinya mudah dipahami, namun siswa akan merasa bosan apabila merasa sulit memahami materinya. Dengan demikian LKS yang dikembangkan dengan 
menggunakan pendekatan saintifik dapat digunakan oleh siswa dan dapat dikatakan praktis sesuai dengan yang disampaikan oleh Agustin tahun 2014 dalam penelitiannya bahwa LKS yang dapat membantu kegiatan pembelajaran dan mendapat respon baik dari siswa dapat dikatakan praktis.

Kekurangan yang ditemukan pada kegiatan uji coba lapangan terbatas kemudian direvisi. Hal ini sesuai dengan teori pengembangan R\&D bahwa setelah produk di uji coba lapangan, akan diketahui kekurangan dari produk yang dikembangkan sehingga kekurangan dari produk tersebut selanjutnya dicoba untuk dikurangi dengan cara memperbaiki produk (Sugiyono, 2016). Tujuan dilakukan revisi produk adalah untuk menyempurnakan produk sehingga benar-benar layak dan praktis digunakan dalam pembelajaran kimia di sekolah.

\section{SIMPULAN DAN SARAN}

Berdasarkan temuan hasil penelitian dan pembahasan pada penelitian ini, dapat disimpulkan bahwa kepraktisan LKS pembelajaran kimia pokok bahasan larutan elektrolit dan nonelektrolit menggunakan pendekatan dinyatakan praktis. LKS menggunakan pendekatan saintifik ini dapat digunakan dan siswa memberikan respon yang positif.

\section{DAFTAR RUJUKAN}

Agustin, M. 2011. Permasalahan Belajar dan Inovasi Pembelajaran. Bandung : PT Refika Aditama

Agustin,M dan Amy T. 2014. Pengembangan Lembar Kerja Siswa (LKS) Berbasis Scientific

Approach dalam Model Pembelajaran Inkuiri Terbimbing Pada Materi Sistem Respirasi untuk Kelas XI SMA Negeri 6 Malang. Tesis (tidak diterbitkan). Universitas Negeri Malang

Daryanto. 2014. Pendekatan Pembelajaran Saintifik Kurikulum 2013. Yogyakarta: Gava Media.

Depdiknas. 2008. Panduan Pengembangan Bahan Ajar. Jakarta: Direktorat Pembinaan SMA, Dirjen Mandikdasmen, Depdiknas.

Diani, R. 2016. "Pengaruh Pendekatan Saintifik Berbantukan Lks Terhadap Hasil Belajar Fisika Peserta Didik Kelas Xi Sma Perintis 1 Bandar Lampung". Jurnal Ilmiah Pendidikan Fisika, volume 5, nomor 2 (hlm 83-93)

Hendro, D \& Kaligis, R.E. 1993. Pendidikan IPA. Jakarta: Dirjen Dikti.

Hosnan. 2014. Pendekatan Saintifik dan Kontekstual dalam Pembelajaran

Abad 21.Bogor: Ghalia Indonesia.

Medina,P. 2015. "Analisis Miskonsepsi Siswa Kelas X Pada Materi Larutan Elektrolit dan Non elektrolit Serta Reaksi Oksidasi dan Reduksi dalam Pembelajaran Kimia Di SMAN Kota Padang". Jurnal Pendidikan dan Teknologi Informasi, Volume 2, nomor 1 (hlm 1-9)

Kesiman, R.D. 2017. Pengembangan Lembar Kerja Siswa (LKS) Berbasis Pendekatan Saintifik dengan Multipresentasi untuk meningkatkan Ketrampilan Proses Sains Siswa SMA Kelas $X$ MIPA. Tesis (tidak diterbitkan). Program Studi Pendidikan IPA, Universitas Pendidikan Ganesha.

Peraturan Menteri Pendidikan dan Kebudayaan Nomor 59 Tahun 2014 Tentang Kerangka Dasar dan Struktur Kurikulum Sekolah Menengah Atas/Madrasah Aliyah. Jakarta: Kemendikbud RI.

Permendikbud RI no 81A Tahun 2013 Tentang Penerapan Kurikulum 2013. Kemdikbud RI: Jakarta.

Prasetyo, I. 2016. Teknik Analisis Data Dalam Research and Development. Jurusan PLS FIP : Universitas Negeri Yogyakarta.

Prastowo, A. 2011. Panduan Kreatif Membuat Bahan Ajar Inovatif :

Menciptakan Metode Pembelajaran yang Menarik, dan Menyenangkan. Yogyakarta : DIFA Press

Prastowo, A. 2013. Pengembangan Bahan Ajar Tematik (tinjauan teoritis dan prktik). Yogyakarta : Kencana 